\title{
Is oral rice electrolyte solution superior to glucose electrolyte solution in infantile diarrhoea?
}

\author{
F C PATRA, D MAHALANABIS, K N JALAN, A SEN, AND P BANERJEE \\ Kothari Centre of Gastroenterology, Calcutta Medical Research Institute, and NRS Medical College and \\ Hospital, Calcutta, India
}

SUMMARY In a controlled trial of oral rehydration therapy, a rice-based electrolyte solution was evaluated in a group $(n=26)$ of infants and young children aged between 3 months and 5 years with moderate to severe dehydration owing to acute diarrhoea, and the results were compared with a matched control group $(n=26)$ receiving WHO recommended glucose electrolyte solution. The former was found to be more effective than the latter as shown by an appreciably lower rate of stool output, a shorter duration of diarrhoea, and a smaller intake of rehydration fluid.

Glucose mediated enhanced sodium absorption forms the basis of oral rehydration therapy in diarrhoea. ${ }^{1}$ Glucose being expensive is not universally available so other carrier substances-such as sucrose-are used. ${ }^{2}$ Rice on hydrolysis yields glucose, amino-acids, and oligopeptides which would enhance sodium absorption through independent carrier systems. ${ }^{3}$ This study describes a randomised trial of a rice-based oral electrolyte solution and compares it with the standard WHO recommended glucose electrolyte solution in infants and young children with dehydration caused by acute diarrhoea.

\section{Patients and methods}

Fifty-two children aged between 3 months and 5 years with acute watery diarrhoea and signs of moderate to severe dehydration ${ }^{4}$ were studied. The nature of the study was clearly explained to the parents, and written consent was obtained from them before the child was included in the study. Each child was weighed naked using a balance with a sensitivity of $1 \mathrm{~g}$. The child was then randomly assigned to either of the two treatment groups by the use of sealed envelopes. The clinical features of the children were comparable (Table 1).

Children in the control group received an oral solution containing sodium $90 \mathrm{mmol} / \mathrm{l}$, potassium $20 \mathrm{mmol} / \mathrm{l}$, chloride $80 \mathrm{mmol} / 1$, bicarbonate 30 $\mathrm{mmol} / \mathrm{l}$, and glucose $111 \mathrm{mmol} / \mathrm{l}$; children in the study groups received an oral solution with an identical electrolyte composition, except that the glucose was replaced by $50 \mathrm{~g} / 1$ of 'pop-rice' powder.
Pop rice is prepared by popping unhusked rice (paddy) on heated sand. It is a traditional rice snack universally consumed in the Indian subcontinent. It was procured from the market and made into a powder form and dissolved in the rehydration fluid $\vec{\bullet}$ before use. The rehydration solution was fed ad lite

Table 1 Presenting features, nutritional status, and aetiological agents

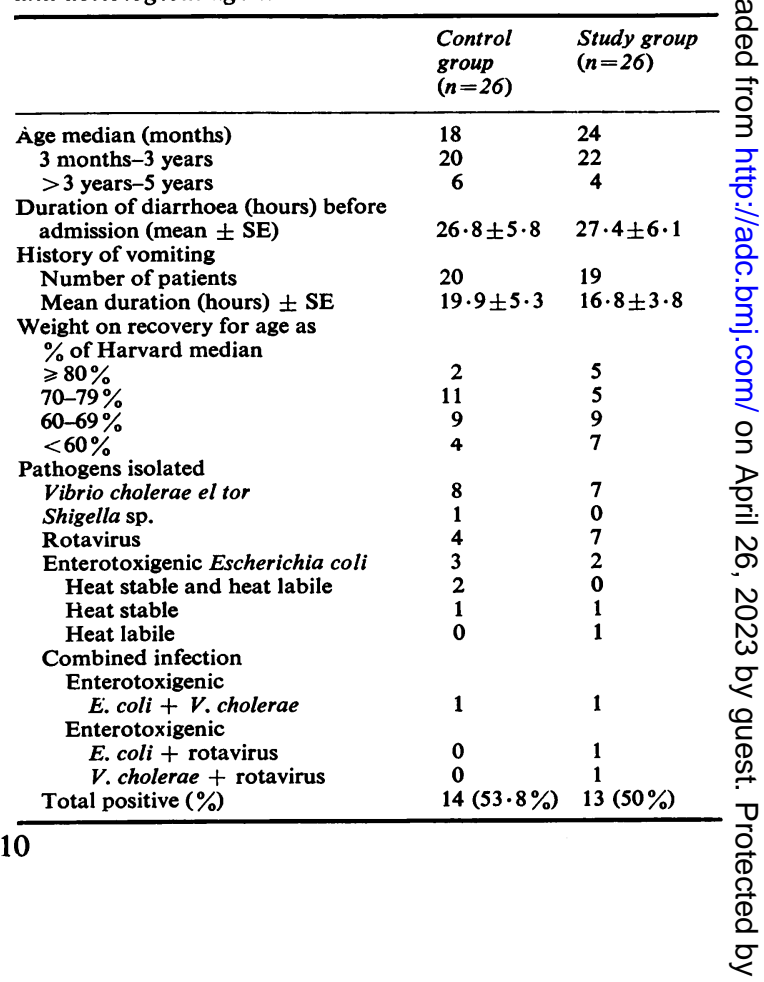


by cup and spoon or directly from a cup. The volume ingested was recorded. Stool output was measured. Altogether $58 \%$ of the children in the control and $69 \%$ in the study group were breast fed. The feeding regimen has been described previously. ${ }^{5}$

\section{Laboratory investigations}

Blood chemistry and stool test for pathogens were carried out using methods which have been previously described. ${ }^{45}$ Protein content of rice was determined by the micro-Kjeldahl method. Statistical analysis was done using Student's $t$ test.

\section{Results}

Two patients in each group could not be rehydrated orally owing to excessive vomiting and diarrhoea that required intravenous therapy. They were excluded from analysis. The remaining patients responded well to oral therapy (Tables 2 and 3). Rice-based oral fluid was accepted well. All patients recovered by 72 hours as judged by passage of formed or semisolid stool. The initial 24-hour and total stool output were significantly lower in the study group compared with the control (Table 2). The study group also consumed less rehydration fluid. Although the mean weight gain at 6,24 , and 48 hours was greater in the study group than in the control one the differences were not significant. Enteropathogens isolated were comparable in both groups (Table 1). Protein content of 'pop-rice' was $87 \mathrm{~g} / \mathrm{kg}$ and on in-vitro acid hydro-

Table 2 Clinical course, weight gain, stool output, oral rehydration solution, plain water intake, and duration of diarrhoea during treatment

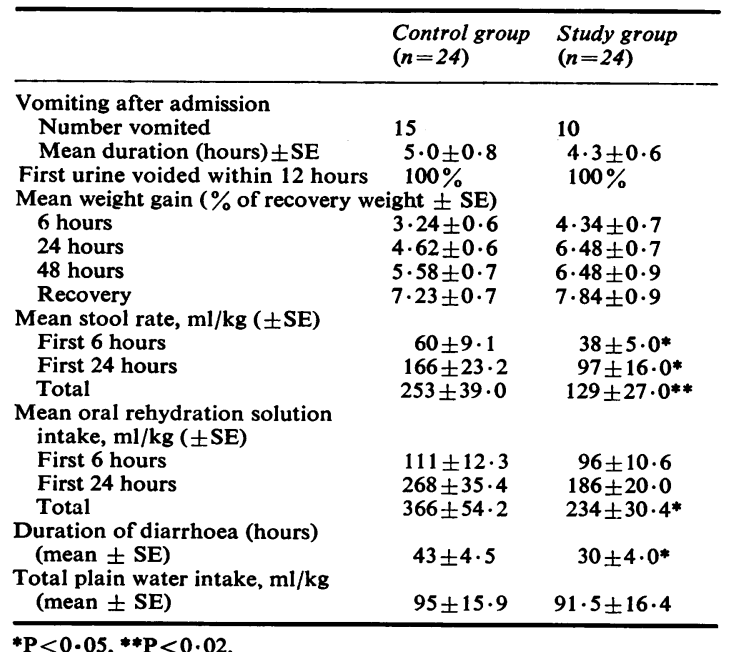

Table 3 Biochemical values (mean $\pm S E$ ) during the study period

\begin{tabular}{|c|c|c|}
\hline & $\begin{array}{l}\text { Control group } \\
(n=24)\end{array}$ & $\begin{array}{l}\text { Study group } \\
(n=24)\end{array}$ \\
\hline \multicolumn{3}{|l|}{ Plasma specific gravity } \\
\hline $\begin{array}{l}\text { Admission (0 hours) } \\
6 \text { hours } \\
\text { Recovery }\end{array}$ & $\begin{array}{l}1.029 \pm 0.001 \\
1.026 \pm 0.001 \\
1.023 \pm 0.001\end{array}$ & $\begin{array}{l}1.028 \pm 0.001 \\
1.025 \pm 0.001 \\
1.022 \pm 0.001\end{array}$ \\
\hline \multicolumn{3}{|l|}{ Haematocrit (\%) } \\
\hline $\begin{array}{l}\text { Admission (0 hours) } \\
6 \text { hours } \\
\text { Recovery }\end{array}$ & $\begin{array}{l}40 \cdot 3 \pm 1 \cdot 5 \\
33 \cdot 5 \pm 1 \cdot 7 \\
31 \cdot 2 \pm 0 \cdot 6\end{array}$ & $\begin{array}{l}39 \cdot 5 \pm 1 \cdot 1 \\
32 \cdot 5 \pm 1 \cdot 2 \\
31 \cdot 6 \pm 0 \cdot 5\end{array}$ \\
\hline \multicolumn{3}{|l|}{$\begin{array}{l}\text { Recovery } \\
\text { Serum sodium (mmol/l) }\end{array}$} \\
\hline $\begin{array}{l}\text { Admission } \\
\text { Recovery }\end{array}$ & $\begin{array}{l}127 \cdot 2 \pm 1 \cdot 5 \\
129 \cdot 6 \pm 1 \cdot 2\end{array}$ & $\begin{array}{l}126 \cdot 7 \pm 1 \cdot 0 \\
129 \cdot 3 \pm 1 \cdot 3\end{array}$ \\
\hline \multicolumn{3}{|l|}{ Serum potassium $(\mathrm{mmol} / \mathrm{l})$} \\
\hline $\begin{array}{l}\text { Admission } \\
\text { Recovery }\end{array}$ & $\begin{array}{l}3 \cdot 7 \pm 0 \cdot 2 \\
4 \cdot 0 \pm 0 \cdot 2\end{array}$ & $\begin{array}{l}4 \cdot 0 \pm 0 \cdot 2 \\
4 \cdot 0 \pm 0 \cdot 1\end{array}$ \\
\hline
\end{tabular}

lysis it liberated $700 \mathrm{~g} / \mathrm{kg}$ of glucose. In the study group the mean $( \pm \mathrm{SE})$ calorie and protein intakes from rice-based solution alone were $40( \pm 5 \cdot 3) \mathrm{cal}$ and $1.02( \pm 0 \cdot 13) \mathrm{g}$ per $\mathrm{kg}$ body weight respectively during an average period of 30 hours.

\section{Discussion}

Rice is cheap, easily obtained (eaten by $60 \%$ of world population), simple to pack (salts alone need to be packaged), and safe (larger quantities if used are unlikely to produce osmotic diarrhoea). In this study $50 \mathrm{~g}$ of precooked rice used in place of $20 \mathrm{~g}$ of glucose in oral rehydration fluid for infants and small children with acute diarrhoea was found to be more effective than the WHO recommended glucose electrolyte solution as judged by stool output, amount of rehydration fluid consumed, and the duration of diarrhoea. Hence rice-based oral solution could be regarded as superior to the extensively tested glucose electrolyte solution, the latter being the most effective oral rehydration solution known so far. In the study group the larger quantity of carbohydrate and the protein content of rice-based solution provides an additional nutritional advantage over glucose electrolyte solution.

A recent study ${ }^{6}$ in adults and older children ( $>5$ years) with cholera and enterotoxigenic Escherichia coli diarrhoea showed that oral electrolyte solution containing $30 \mathrm{~g} / 1$ of cooked rice powder was as effective as a sucrose electrolyte solution.

We thank Dr P K Talukdar, Dr S Roychoudhury, and Dr M I Huq for assistance.

\section{References \\ 1 Mahalanabis D. Rehydration therapy in diarrhoea. In: Holme T, Holmgren J, Merson M H, Mollby R, eds. Acute enteric infections in children: new prospects for}


treatment and prevention. Amsterdam: Elsevier/North Holland, 1981 : 303-18.

2 Chatterjee A, Mahalanabis D, Jalan K N, et al. Evaluation of a sucrose/electrolyte solution for oral rehydration in acute infantile diarrhoea. Lancet $1977 ; \mathbf{i}: 1333-5$.

${ }^{3}$ Schultz S G. Sodium-coupled solute transport by small intestine: a status report. $A m J$ Physiol 1977; 223: E249-54.

4 Chatterjee A, Mahalanabis D, Jalan K N, et al. Oral rehydration in infantile diarrhoea. Arch Dis Child 1978; 53: 284-9.

5 Patra F C, Mahalanabis D, Jalan K N, Sen A, Banerjee P. Can acetate replace bicarbonate in oral rehydration solution for infantile diarrhoea? Arch Dis Child 1982; 57: 625-7.

- Molla A M, Sarker S A, Hossain M, Molla Ayesha, Greenough W B. The successful use of (rice powder) electrolyte solution as oral therapy in diarrhoea due to $\bar{F}$ $V$. cholerae and E. coli. Lancet 1982; i: 1317-9.

Correspondence to Dr D Mahalanabis, Kothari Centre of Gastroenterology, 7/2 Diamond Harbour Road, Calcutta 700 027, India.

Received 16 August 1982

\section{The following articles will appear in future issues of this journal:}

Effects of routine care procedures on transcutaneous oxygen in neonates: a quantitative approach D A Danford, S Miske, J Headley, and $R M$ Nelson

Asthma and infant diet

$D M$ Fergusson, $L J$ Horwood, $F T$ Shannon

Identification of lymphocyte subsets in the newborn using a variety of monoclonal antibodies $R M$ Thomas and D C Linch

Teenage mothering, time in hospital, and accidents during the first 5 years

$B$ Taylor, $J$ Wadsworth, and $N$ R Butler

Costs of visiting babies in special care baby units

$M A$ Smith and $J$ D Baum

Haemolytic-uraemic syndrome: an analysis of prognostic features

$R S$ Trompeter, $R$ Schwartz, C Chantler, MJ Dillon, $G$ B Haycock, $R$ Kay, and $T M$ Barratt

Diagnostic and prognostic value of fibrin stabilising factor in Schönlein-Henoch syndrome $B$ Dalens, $P$ Travade, A Labbe, and M J Bezou 